\title{
REVISED Bibliometric analysis of Oropouche research: impact on the surveillance of emerging arboviruses in Latin America
}

\section{[version 2; peer review: 3 approved]}

\section{Carlos Culquichicón (D1-3, Jaime A. Cardona-Ospina3,4, Andrés M. Patiño-Barbosa3, Alfonso J. Rodriguez-Morales (iD) 3,4}

\footnotetext{
${ }^{1}$ Emerge, Emerging Diseases and Climate Change Research Unit, Universidad Peruana Cayetano Heredia, Lima, Peru

${ }^{2}$ Scientia Clinical and Epidemiological Research Institute, Trujillo, Peru

${ }^{3}$ Public Health and Infection Research Group, Faculty of Health Sciences, Universidad Tecnologica de Pereira, Pereira, Risaralda, Colombia

${ }^{4}$ Colombian Collaborative Network of Zika and other Arboviruses (RECOLZIKA), Pereira, Risaralda, Colombia
}

V2 First published: 28 Feb 2017, 6:194

https://doi.org/10.12688/f1000research.10936.1

Latest published: 17 Mar 2017, 6:194

https://doi.org/10.12688/f1000research.10936.2

\section{Abstract}

Given the emergence and reemergence of viral diseases, particularly in Latin America, we would like to provide an analysis of the patterns of research and publication on Oropouche virus (OROV). We also discuss the implications of recent epidemics in certain areas of South America, and how more clinical and epidemiological information regarding OROV is urgently needed.

\section{Keywords}

Oropouche, arbovirus, epidemiology, public health, travelers, Latin America

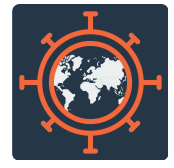

This article is included in the Emerging Diseases and Outbreaks gateway.

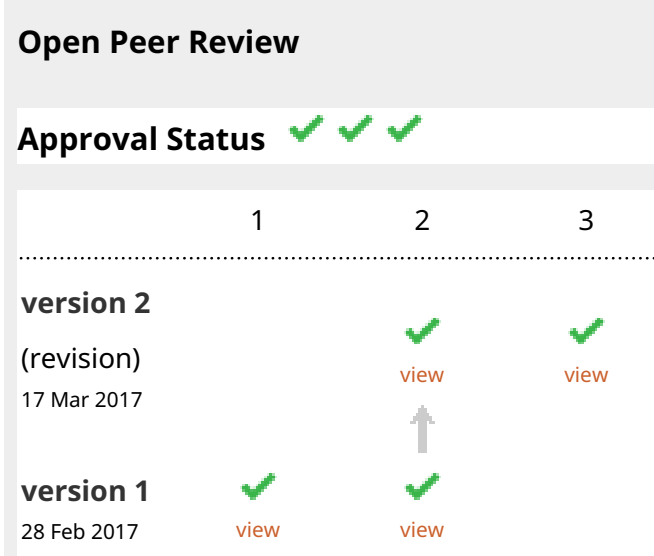

1. Kateryna Kon, Kharkiv National Medical University, Kharkiv, Ukraine

2. Luis Cuauhtémoc Haro-García (iD), National Autonomous University of Mexico (UNAM), Mexico City, Mexico

3. Rodrigo Nogueira Angerami, University of Campinas (UNICAMP), Campinas, Brazil

Any reports and responses or comments on the article can be found at the end of the article. 
Corresponding author: Alfonso J. Rodriguez-Morales (ajrodriguezm_md@hotmail.com)

Competing interests: No competing interests were disclosed.

Grant information: This study was partially funded by the Universidad Tecnologica de Pereira (UTP), Pereira, Risaralda, Colombia. Presentation of this study at the IV Latin American Congress of Travel Medicine (SLAMVI), Buenos Aires, Argentina, October 6-7, 2016, was funded by CTO Colombia, UTP and the Latin American Society for Travel Medicine (SLAMVI). The funders had no role in study design, data collection and analysis, decision to publish, or preparation of the manuscript. The funders had no role in study design, data collection and analysis, decision to publish, or preparation of the manuscript.

Copyright: $\odot 2017$ Culquichicón C et al. This is an open access article distributed under the terms of the Creative Commons Attribution License, which permits unrestricted use, distribution, and reproduction in any medium, provided the original work is properly cited. Data associated with the article are available under the terms of the Creative Commons Zero "No rights reserved" data waiver (CC0 1.0 Public domain dedication).

How to cite this article: Culquichicón C, Cardona-Ospina JA, Patiño-Barbosa AM and Rodriguez-Morales AJ. Bibliometric analysis of Oropouche research: impact on the surveillance of emerging arboviruses in Latin America [version 2; peer review: 3 approved] F1000Research 2017, 6:194 https://doi.org/10.12688/f1000research.10936.2

First published: 28 Feb 2017, 6:194 https://doi.org/10.12688/f1000research.10936.1 


\section{REVISED Amendments from Version 1}

This new version considered interesting comments of one of the reviewers regarding the participation of non-Latin American countries in the OROV research, considerations on the output and related factors from Brazil(as the leader in the field), as well as findings at additional databases (LILACS, SciELO and IMBIOMED), where additional results were considered.

See referee reports

\section{Introduction}

The Oropouche virus (OROV) is an emerging arbovirus that threatens the Amazon region of Brazil, Peru, and Venezuela ${ }^{1}$. The coexistence of this pathogen with other long-term circulating arboviruses, such as dengue virus (DENV), West Nile virus (WNV), Venezuelan Equine Encephalitis (VEEV) and yellow fever virus (YFV), as well as emerging arboviruses such as chikungunya (CHIKV), Zika (ZIKV) and Mayaro virus (MAYV), may hinder clinical diagnosis and successful vector-control strategies ${ }^{2}$. Research is essential to be able to manage this complex scenario. As has been highlighted by Ballabeni and Boggio $^{3}$, bibliometric analyses of publications on emerging and reemerging viral diseases are important as they may lead to insights on how the global scientific and health communities react to outbreaks. We aimed to conduct a bibliometric analysis of OROV research and the impact on the surveillance of emerging and re-emerging arboviruses in Latin America.

\section{Methods}

A bibliometric study was done about OROV scientific production, with a focus on Latin America. We searched in three important regional and international databases (all of them in English): Science Citation Index Expanded (SCI-E), Scopus, Medline (via GoPubMed®), LILACS, SciELO and IMBIOMED.

This search strategy used the following key words (MeSH, Medical Subject Headings): "Oropouche" AND "Latin America", "Oropouche" AND "Argentina", "Oropouche" AND "Colombia", and the same way with the rest of the Latin American countries. Also, "OROV" was used instead of Oropouche for additional searches. All study types were included (original articles, reviews, case reports, editorials) and were categorized by year, international cooperation, city and institution, journal and authors with major contribution. Searches were done from May 30 to June 30, 2015.

Data was tabulated and analyzed in Excel 2007® for Windows $7{ }^{\circledR}$ (Dataset $1^{4}$ ), summarizing quantitative variables with means and interquartile ranges (IQRs), and qualitative variables with proportions.

Dataset 1. Raw data obtained from bibliographical databases (Medline, Scopus and SCI-E)

http://dx.doi.org/10.5256/f1000research.10936.d152949

\section{Results}

A total of 260 related records were retrieved in our search; from these, 97 manuscripts were recovered in Scopus (55\% from Brazil, 28\% from US, and 11\% from Peru); 83 articles were recovered from Medline (43\% from Brazil, 18\% from US, and 6\% from Peru) and 80 articles were recovered from SCI-E (61\% from Brazil, 35\% from US, and 15\% from Peru) (Table 1). As observed in Medline, publications on OROV never reached more than 3 articles per year (Figure 1). Analyzing this database, it can be observed that Brazil has the more productive and cooperative research groups in Latin America (Figure 1).

For Scopus, the annual average number of articles published up to 2014 was 5 (IQR: 1-17) (Figure 2). In June 2015, only two articles had been published that year. Nevertheless, after 1996, although not uniform, there was an increasing trend in the number of articles published on OROV per year, reaching 9 in 2011 (Figure 2). At Scopus 19 countries contributed to the publication of at least 1 paper during the study period (Figure 3). For SCI-E, the annual average number of articles published up to 2014 was 6.2 (IQR: 1-20), with 16 countries contributing to the publication of at least 1 paper during the study period (Figure 4).

Table 1. Countries with highest scientific output on Oropouche, using data taken from Science Citation Index-Expanded, Scopus and/or Medline (up to June 30, 2015).

\begin{tabular}{|c|c|c|c|}
\hline Rank & Country & $\begin{array}{l}\text { Number of } \\
\text { articles }\end{array}$ & $\begin{array}{l}\text { Database } \\
\text { with highest } \\
\text { number of } \\
\text { articles }\end{array}$ \\
\hline 1 & Brazil & 53 & SCOPUS \\
\hline 2 & United States & 28 & SCl-E \\
\hline 3 & Peru & 12 & SCI-E \\
\hline 4 & Trinidad and Tobago & 8 & SCOPUS \\
\hline 4 & United Kingdom & 8 & SCl-E \\
\hline 5 & Canada & 7 & SCOPUS \\
\hline 6 & Germany & 5 & SCI-E \\
\hline 7 & Argentina & 3 & SCI-E \\
\hline 7 & Paraguay & 3 & SCI-E \\
\hline 8 & Argentina & 2 & SCOPUS \\
\hline 8 & Netherlands & 2 & SCl-E \\
\hline 8 & Ecuador & 2 & SCI-E \\
\hline 9 & Australia & 1 & SCOPUS \\
\hline 9 & Bolivia & 1 & SCOPUS \\
\hline 9 & Australia & 1 & SCl-E \\
\hline 9 & Argentina & 1 & Medline \\
\hline 9 & Czech Republic & 1 & Medline \\
\hline 9 & Norway & 1 & Medline \\
\hline 9 & Trinidad and Tobago & 1 & Medline \\
\hline
\end{tabular}




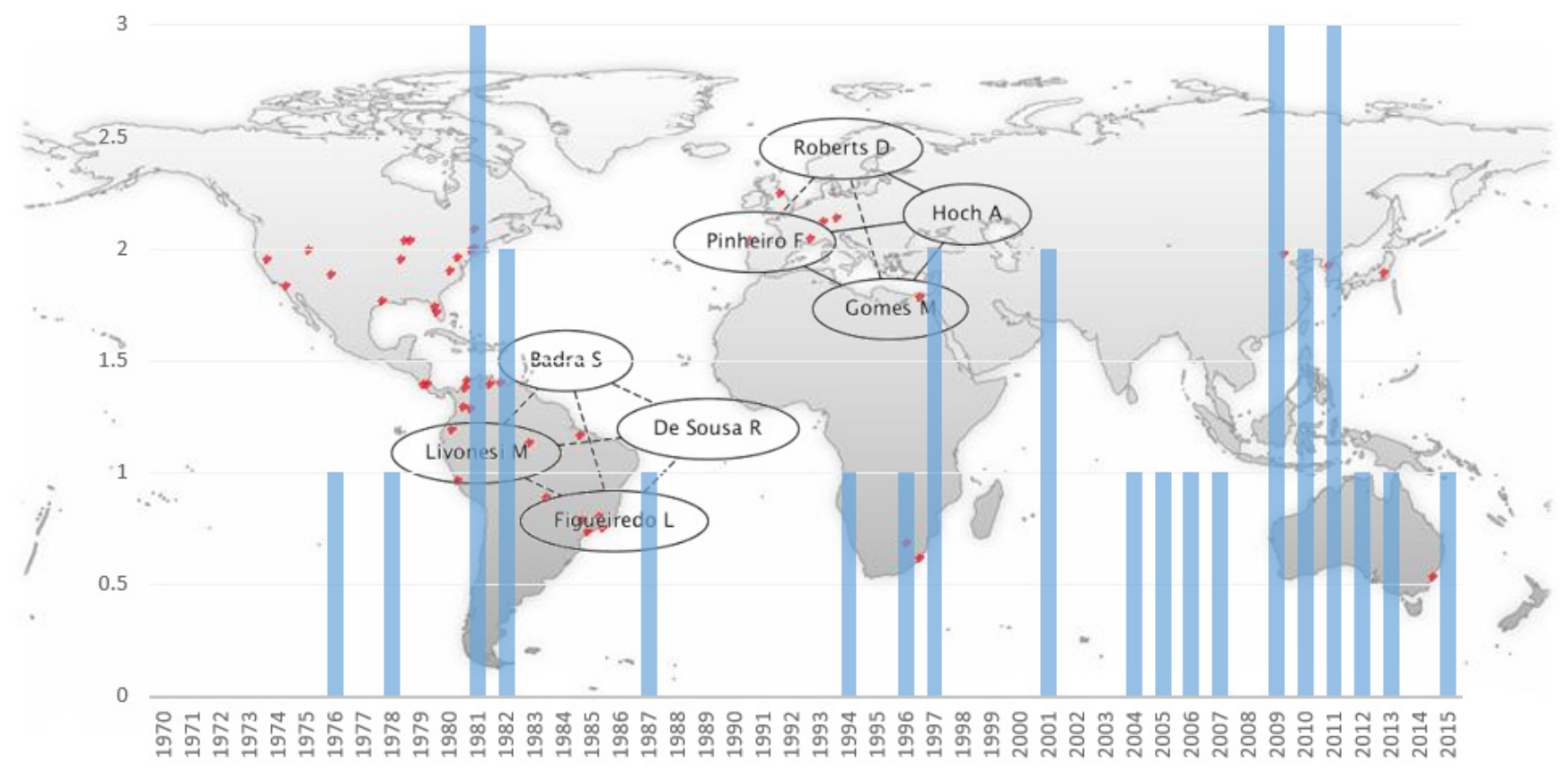

Figure 1. Graphical representation of major international research networks involved in research on Oropouche (via GoPubMed®) and research trends from 1970 to 2015.

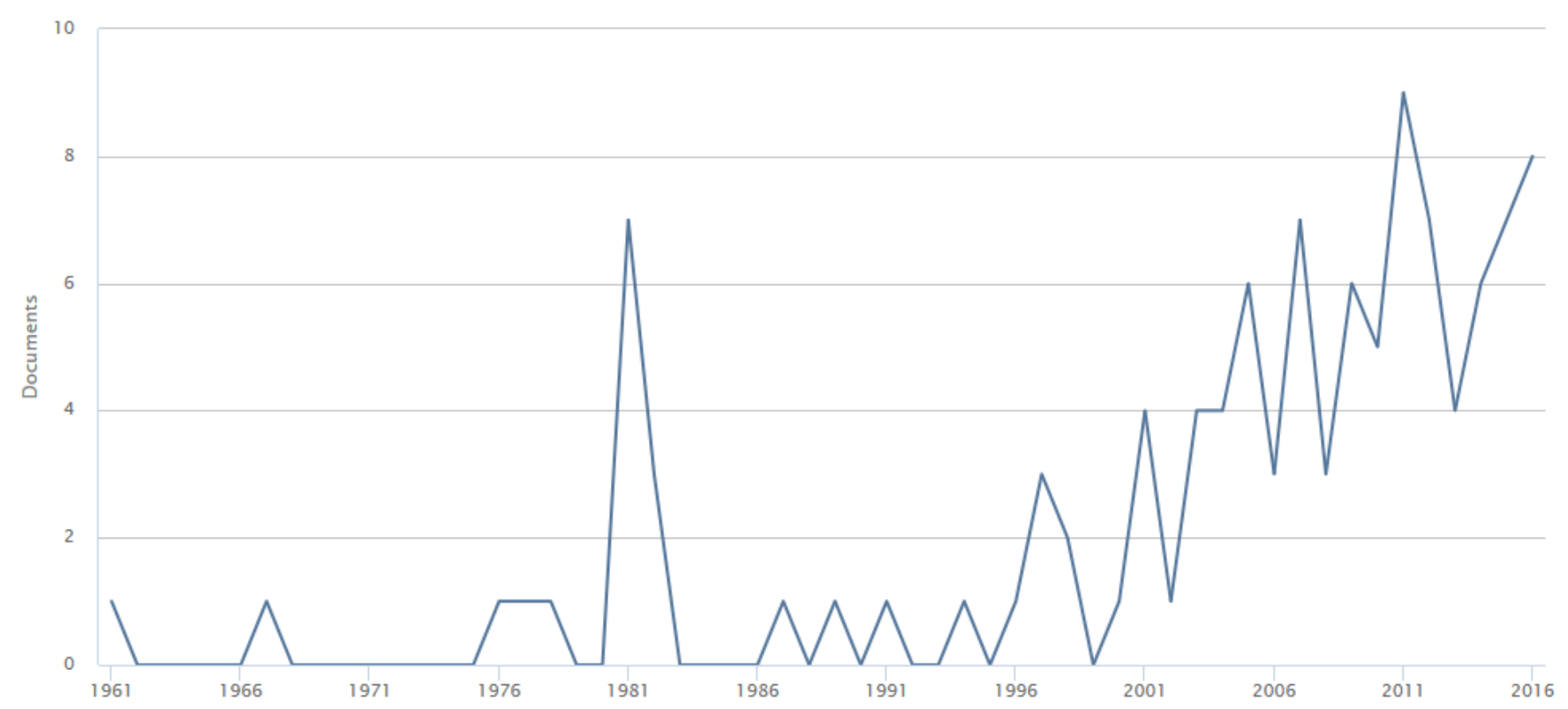

Figure 2. Research trends on Oropouche virus from 1960 to 2016. Data taken from Scopus. 


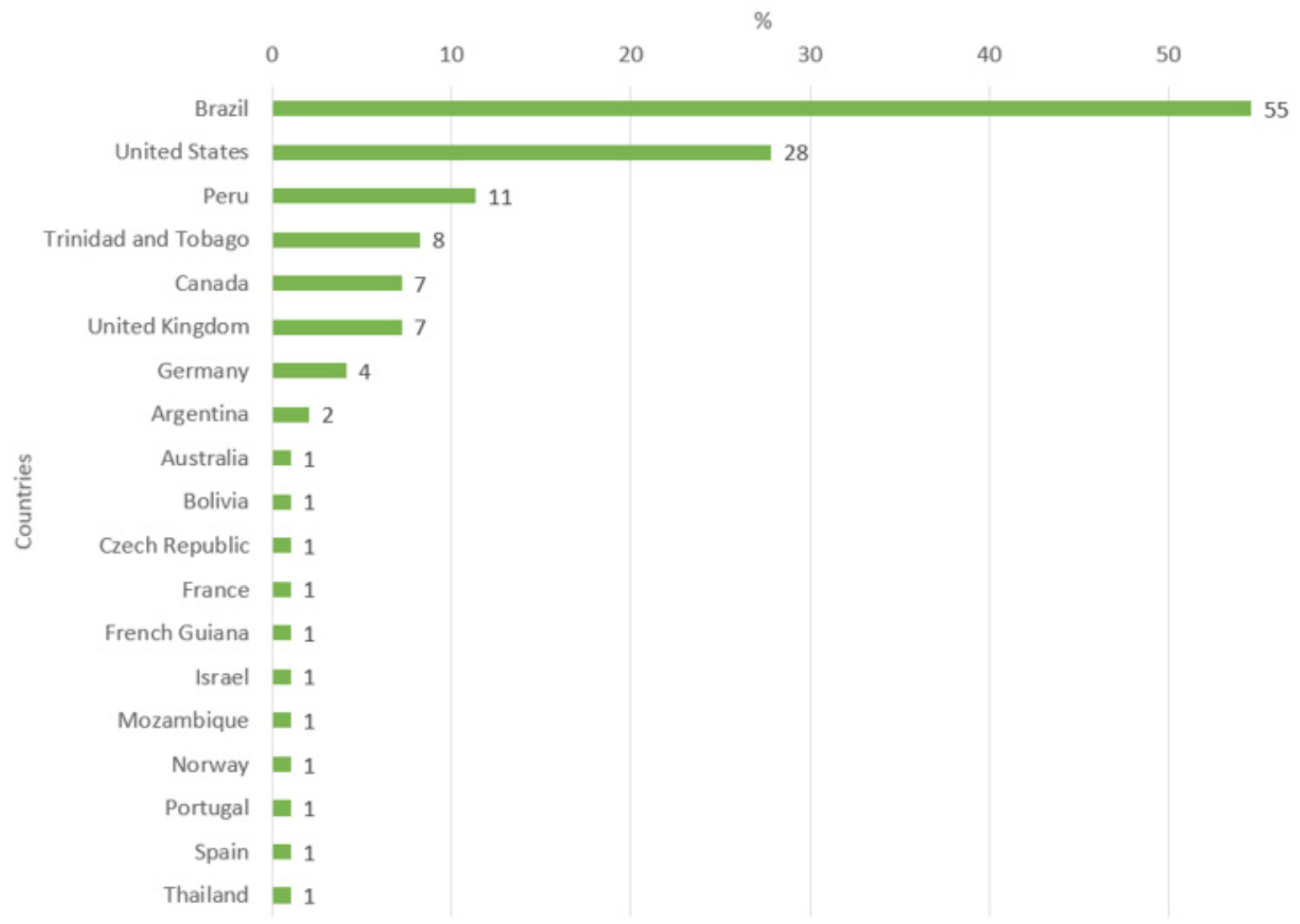

Figure 3. Research on Oropouche virus, ranked by contributing countries (\%). Data taken from Scopus.

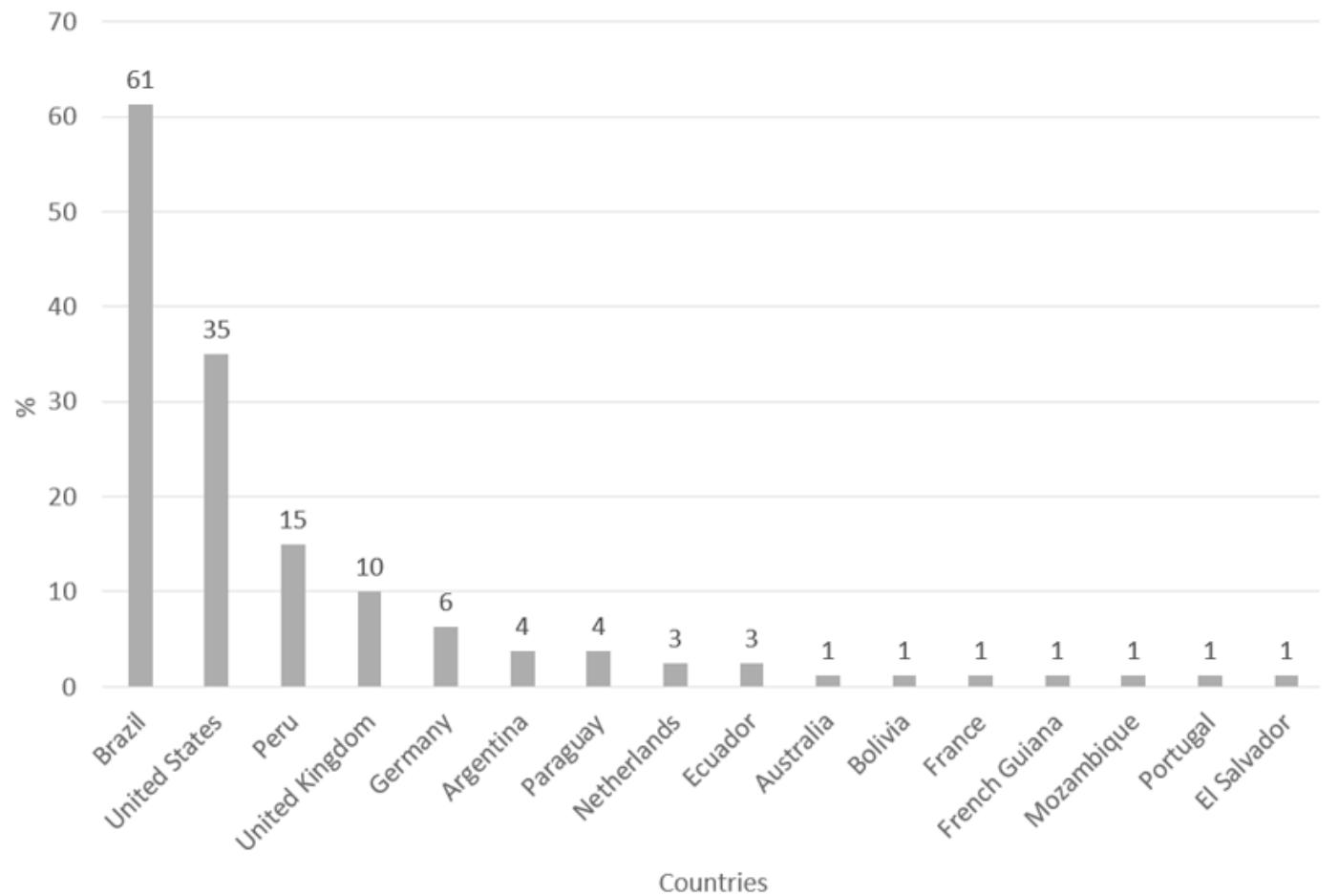

Figure 4. Research on Oropouche virus, ranked by contributing countries (\%). Data taken from SCI-E. 
"Universidade de Sao Paulo" in Sao Paulo, Brazil, was the institution with the most prolific research contribution, and "Figueiredo, L.T.M" was the author with the longest record in Oropouche research, with 12 articles (Figure 1 and Figure 2). The greatest $\mathrm{H}$-indexes for Oropouche issues came from Brazil (H-index=12, 431 citations), the United States of America ( $\mathrm{H}$-index=10, 339 citations), Peru (H-index=9, 234 citations), United Kingdom (H-index=6, 144 citations), Canada $(\mathrm{H}$-index $=5$, 155 citations) and Trinidad and Tobago (H-index =4, 92 citations).

In the case of LILACS, only 35 articles were retrieved, 26 of them from Brazil, 3 from Peru, 1 from Argentina, 1 from Paraguay and 1 from Venezuela. Of them, 10 were published in the journal Revista da Sociedade Brasileira de Medicina Tropical. The year with the highest number of articles published at this database was 1982 with 5

At SciELO, 22 articles were located, 18 from the Brazil collection and 1 from Peru collection, published mainly between 2015-2016 (6 articles), being 12 in English, 8 in Portuguese and 2 in Spanish.

Finally, at IMBIOMED none results were found.

\section{Discussion}

OROV outbreaks increase when the rainy season starts (January to June) in endemic areas, where the population density of Culicoides paraensis is high ${ }^{1}$. In fact, the OROV dispersion routes and its genetic diversity ${ }^{5}$ impacted on the growth of scientific publications, as well as on the international collaboration on this topic. On the $2^{\text {nd }}$ of May 2016, the Ministry of Health of Peru reported 57 cases of OROV fever ${ }^{6}$. Most cases originate in towns located in the northern part of the Cusco Region, which is situated in the Amazon rainforest. 79\% were detected in January, with only $7 \%$ and $14 \%$ of the cases being identified in February and March, respectively. There were no fatalities and all patients have recovered following symptomatic treatment. In February 2016, a field mission to the Madre de Dios Region conducted jointly by the Ministry of Health of Peru and PAHO/WHO revealed a mixed outbreak of dengue (DENV-2) and OROV. While Madre de Dios already experienced an outbreak of OROV fever in 1994, at the time of the mission in February, this latest outbreak was of a higher magnitude, with 120 confirmed cases ${ }^{6}$. Cases have also been reported in other nearby countries such as Panama, Trinidad and Tobago and Brazil, and very recently in Venezuela (2016) ${ }^{1,7}$. It highlights the potential for expansion of OROV and other related reassortant viruses to other countries in the region, such as Colombia, Venezuela and Ecuador, amongst others in South and Central America.
Despite this epidemiological situation, research on OROV is far below the level of research on other emerging arboviruses in Latin America such as CHIKV (6,344 articles recovered) or ZIKV ${ }^{8,9}$. This lack of published studies does not allow evidence-based decision-making on public health policies. More clinical and epidemiological information regarding OROV is urgently needed. Especially in highly vulnerable areas, such as those where other arboviruses (CHIKV, ZIKV, DENV) are circulating because vector and climate conditions are suitable for transmission ${ }^{10-13}$, research on OROV deserves more incentives among institutions, so that specific laboratory tests can be designed and more knowledge on this this emerging arbovirus can be gathered properly $^{2,10-13}$. Currently, differential diagnosis of these arboviruses (CHIKV, DENV, ZIKV, MAYV) poses a significant challenge ${ }^{10}$, especially in the scenario of co-circulation and/or syndemics with emerging and circulating arboviruses, or even in the scenario of co-infections ${ }^{10-13}$

The current bibliometric analysis was not restricted to Latin American countries. Although this is an arbovirus that emerged in the region, there is interest from international groups to cooperate in the research on OROV from outside Latin America. Even more, Latin America can be the source of imported cases in North America and Europe, as has been happening not just with arboviral diseases $^{9,10}$, but also with Chagas disease. When revising the bibliometric analysis to take into account such a situation, it can be seen that there are research groups outside Latin America contributing to research about this disease. Then, countries such as USA, Canada andSpain, among others, would be concerned about the potential impact of the spread of this arbovirus outside Latin America ${ }^{14}$.

In conclusion, Brazil is leading the initiative on OROV research. Probably this country is the main contributor since its budget for science is one of the highest in Latin America, and not necessarily because it suffers in a greater proportion of this problem. Nevertheless, OROV infection is a differential diagnosis in the Amazonas area of Brazil. Besides this, international research networks should be expanded to gain a full understanding of this arboviral disease and explore its potential expansion and impact. To do this, the epidemic dispersion, transmission cycle, molecular epidemiology, pathogenesis, and clinical features of OROV need to be studied.

\section{Data availability}

Dataset 1: Raw data obtained from bibliographical databases (Medline, Scopus and SCI-E).

DOI, 10.5256/f1000research.10936.d1529494 
Author contributions

Study design: AJRM. Data collection: CC, JACO, AMPB. Data analysis: AJRM, JACO. All authors were involved in the writing and read the final version submitted.

\section{Competing interests}

No competing interests were disclosed.

\section{Grant information}

This study was partially funded by the Universidad Tecnologica de Pereira (UTP), Pereira, Risaralda, Colombia. Presentation of this study at the IV Latin American Congress of Travel Medicine (SLAMVI), Buenos Aires, Argentina, October 6-7, 2016, was funded by CTO Colombia, UTP and the Latin American Society for Travel Medicine (SLAMVI).

The funders had no role in study design, data collection and analysis, decision to publish, or preparation of the manuscript.

\section{Acknowledgments}

This study was previously selected for oral presentation and presented in part at the IV Latin American Congress of Travel Medicine (SLAMVI) in Buenos Aires, Argentina, $6^{\text {th }}-7^{\text {th }}$ October, 2016.
1. da Rosa JF, de Souza WM, de Paula Pinheiro F, et al:: Oropouche Virus: Clinical, Epidemiological, and Molecular Aspects of a Neglected Orthobunyavirus. Am J Trop Med Hyg. 2017; pii: 16-0672. PubMed Abstract | Publisher Full Text

2. Rodríguez-Morales AJ, Paniz-Mondolfi AE, Villamil-Gómez WE, et al:: Mayaro, Oropouche and Venezuelan Equine Encephalitis viruses: Following in the footsteps of Zika? Travel Med Infect Dis. 2016; pii: S1477-8939(16)30167-3. PubMed Abstract | Publisher Full Text

3. Ballabeni A, Boggio A: Publications in PubMed on Ebola and the 2014 outbreak [version 2; referees: 2 approved]. Version 2. F1000Res. 2015; 4: 68. PubMed Abstract | Publisher Full Text | Free Full Text

4. Culquichicón C, Cardona-Ospina JA, Patiño-Barbosa AM, et al:: Dataset 1 in: Bibliometric analysis of Oropouche research: impact on the surveillance of emerging arboviruses in Latin America. F1000Research. 2017. Data Source

5. Vasconcelos HB, Nunes MR, Casseb LM, et al:: Molecular Epidemiology of Oropouche Virus, Brazil. Emerg Infect Dis. 2011; 17(5): 800-6. PubMed Abstract | Publisher Full Text | Free Full Text

6. WHO: Oropouche virus disease - Peru. Disease Outbreak News. 2016; Date accessed: October 1, 2016 Reference Source

7. Navarro JC, Giambalvo D, Hernandez R, et al.: Isolation of Madre de Dios Virus (Orthobunyavirus; Bunyaviridae), an Oropouche Virus Species Reassortant, from a Monkey in Venezuela. Am J Trop Med Hyg. 2016; 95(2): 328-38. PubMed Abstract | Publisher Full Text | Free Full Text

8. Vera-Polania F, Muñoz-Urbano M, Bañol-Giraldo AM, et al:: Bibliometric assessment of scientific production of literature on chikungunya. $J$ Infect Public Health. 2015; 8(4): 386-8.

PubMled Abstract | Publisher Full Text

9. Martinez-Pulgarin DF, Acevedo-Mendoza WF, Cardona-Ospina JA, et al:: A bibliometric analysis of global Zika research. Travel Med Infect Dis. 2016; 14(1) 55-7. PubMed Abstract | Publisher Full Text

10. Paniz-Mondolfi AE, Rodriguez-Morales AJ, Blohm G, et al:: ChikDenMaZika Syndrome: the challenge of diagnosing arboviral infections in the midst of concurrent epidemics. Ann Clin Microbiol Antimicrob. 2016; 15(1): 42. PubMed Abstract | Publisher Full Text | Free Full Text

11. Villamil-Gómez WE, Rodríguez-Morales AJ, Uribe-García AM, et al:: Zika, dengue, and chikungunya co-infection in a pregnant woman from Colombia. Int $J$ Infect Dis. 2016; 51: 135-138.

PubMed Abstract | Publisher Full Text

12. Paniz-Mondolfi AE, Villamil-Gómez WE, Rodríguez-Morales AJ: Usutu virus infection in Latin America: A new emerging threat. Travel Med Infect Dis. 2016; 14(6): 641-643

PubMed Abstract | Publisher Full Text

13. Rodriguez-Morales AJ, Villamil-Gómez WE, Franco-Paredes C: The arboviral burden of disease caused by co-circulation and co-infection of dengue, chikungunya and Zika in the Americas. Travel Med Infect Dis. 2016; 14(3): 177-9. PubMed Abstract | Publisher Full Text

14. Delgado-Osorio N, Vera-Polania F, Lopez-Isaza AF, et al.: Bibliometric assessmen of the contributions of literature on Chagas disease in Latin America and the Caribbean. Recent Pat Antiinfect Drug Discov. 2014; 9(3): 202-208. PubMed Abstract | Publisher Full Text 


\section{Open Peer Review}

\section{Current Peer Review Status:}

\section{Version 2}

Reviewer Report 10 April 2017

https://doi.org/10.5256/f1000research.12074.r20659

(C) 2017 Angerami R. This is an open access peer review report distributed under the terms of the Creative Commons Attribution License, which permits unrestricted use, distribution, and reproduction in any medium, provided the original work is properly cited.

\section{Rodrigo Nogueira Angerami}

Faculty of Medical Sciences, Department of Clinical Medicine, Clinical Hospital, University of Campinas (UNICAMP), Campinas, Brazil

The present manuscript discusses an important issue in the current epidemiological scenario: the importance of arboviral diseases as a health problem worldwide. Despite the important of the recognition and knowledge of certain diseases in this group, they present quite a heterogeneous public health challenge to sanitary authorities, both as a medical problem for healthcare professions, and a risk to the health of the general populace. While dengue and, more recently, Zika and chikungunya, reached a high level of recognition, priority, "notoriety", Oropouche fever, certainly, does not appears to be part of this group.

The subject of this paper is an interesting insight regarding how much Oropouche is also potentially put down as an object of study and interest of research. Additionally, it identifies where the hotspots of scientific production are, who are potential partners for scientific cooperation projects and what the main databases for bibliographic revision are.

Some questions, however, must be addressed:

- In the introduction, authors included West Nile, besides dengue (as an example) as a long-term circulating virus. Not in Latin America, especially if considering the South America.

- Why not include other indicators as to the patterns of study design (review, case series, case report ...) and the journals impact factor.

- It would be interesting to correlate/compare, by country and year/period, the number of described/reported cases in the papers with those reported/notified (or not) found in the official databases.

- In table 1, it would be recommended to include a "Total" in the last line and a "\%" column besides "number of articles" column.

- It is potentially confusing to have "geographical representation of major international research networks" and "research trends" in the same figure (figure 1).

- As a suggestion, in the discussion there is a lot of text on a single example, at Peru. It would be more interesting and illustrative to describe the occurrence along the time of first cases and, specifically, outbreaks in Latin American countries. 
Competing Interests: No competing interests were disclosed.

I confirm that I have read this submission and believe that I have an appropriate level of expertise to confirm that it is of an acceptable scientific standard.

Author Response 11 Apr 2017

Alfonso Rodriguez-Morales, Fundación Universitaria Autónoma de las Américas, Colombia

Dear Dr. Angerami

In the first place, thanks for your review and valuable comments on the version 2 of our article. As you stated, other arboviruses different to dengue, chikungunya and Zika, have been less than these in the epidemiological and research spotlight, although would be also important, and in the current and future scenario of Latin America should be considered for both aspects as well in the possible differential diagnosis of tropical diseases.

We agree that Oropouche is relevant and deserves more interest of research. That was in part the reason of our bibliometric study.

Regard your specific comments:

- In the introduction, authors included West Nile, besides dengue (as an example) as a long-term circulating virus. Not in Latin America, especially if considering the South America.

Both arboviruses, specially dengue, have been detected and are circulating in Latin America, both Central and South Americas. We will add a comment on it in the version 3, based on this revision.

- Why not include other indicators as to the patterns of study design (review, case series, case report ...) and the journals impact factor.

Regarding the study design, this is possible only, and with large limitation, in Medline and Scopus. Nevertheless and trying to attend all the reviewers' comments, we will add results about it. In the same way for the journals where OROV research has been published and their impact factors (for those journals included at SCI-E/WoS).

- It would be interesting to correlate/compare, by country and year/period, the number of described/reported cases in the papers with those reported/notified (or not) found in the official databases.

Certainly, we agree that this would be very interesting. Nevertheless, is not possible to do it, because such data does not exist nor is available. There are not "official databases" with OROV cases.

- In table 1, it would be recommended to include a "Total" in the last line and a "\%" column besides "number of articles" column.

The table 1 was constructed with the top countries in terms of scientific output on OROV research in SCI-E, Medline and Scopus, then it is not possible to include that in the table. Such information is in the text at the different parts of Results section. This is a summary. 
- It is potentially confusing to have "geographical representation of major international research networks" and "research trends" in the same figure (figure 1). This manuscript is a Research Note (Brief or Short Communication), not a full original research article. Then, we developed a shorter manuscript. In all the previously bibliometric studies, from our group, as well published by others, these kind of figures have been developed and published, without confusion. It is clear enough.

- As a suggestion, in the discussion there is a lot of text on a single example, at Peru. It would be more interesting and illustrative to describe the occurrence along the time of first cases and, specifically, outbreaks in Latin American countries.

We will add more information about this in the discussion, as since we published the version 1 up to current day there have been new articles showing more information from other countries different to Peru.

Competing Interests: None.

Reviewer Report 20 March 2017

https://doi.org/10.5256/f1000research.12074.r21111

(c) 2017 Haro-García L. This is an open access peer review report distributed under the terms of the Creative Commons Attribution License, which permits unrestricted use, distribution, and reproduction in any medium, provided the original work is properly cited.

\section{Luis Cuauhtémoc Haro-García}

Department of Public Health, Faculty of Medicine, National Autonomous University of Mexico (UNAM), Mexico City, Mexico

I have no further comments.

Competing Interests: No competing interests were disclosed.

I confirm that I have read this submission and believe that I have an appropriate level of expertise to confirm that it is of an acceptable scientific standard.

\section{Version 1}

Reviewer Report 15 March 2017

https://doi.org/10.5256/f1000research.11788.r20599 
(C) 2017 Haro-García L. This is an open access peer review report distributed under the terms of the Creative Commons Attribution License, which permits unrestricted use, distribution, and reproduction in any medium, provided the original work is properly cited.

\section{Luis Cuauhtémoc Haro-García}

Department of Public Health, Faculty of Medicine, National Autonomous University of Mexico (UNAM), Mexico City, Mexico

The title of the manuscript seems to me appropriate, the summary is clear enough as to the purpose of the study. The design is adequate and sufficiently explained. The discussion chapter is balanced in such a way that it will be able to draw the attention of the scientific community on this emerging arbovirus in the region of Latin America.

Further Comments:

- If some of the contributions for non-Latin American countries (the United States, Canada, Australia, Norway, Thailand and others), were carried out in a Latin America country or in their own country, please say the reason for including them in the bibliometric analysis.

- Although the bibliometric analysis that was performed apparently fulfills the objective of the study ----but it includes results of non-Latin American countries---it would have been interesting to know if the scientific production of nations of other regions of the world share the concern they should be taking into account more the emergency and re-emergence of this arbovirus.

- It would be appropriate to discuss, by the authors, that Brazil probably is the main contributor to the issue because its budget for science is one of the highest in Latin America, and not because it suffers in a greater proportion of this problem, or if there are other reasons.

- It would have been desirable to consider some regional bibliographic databases such as LILACS and IMBIOMED, and not just English-speaking ones for a best bibliometric analysis, or to indicate why they were not taken into account.

I have read this submission and believe that I have the level of expertise to indicate that the study has the sufficient scientific standard

Competing Interests: No competing interests were disclosed.

\section{I confirm that I have read this submission and believe that I have an appropriate level of expertise to confirm that it is of an acceptable scientific standard.}

Author Response 15 Mar 2017

Alfonso Rodriguez-Morales, Fundación Universitaria Autónoma de las Américas, Colombia

Dear Dr. Haro-García

Thanks for your comments. 
The current bibliometric analysis was not restricted to Latin American countries, although this is an arbovirus that emerged in the region, there is interest from international groups to cooperate in the research on OROV from outside Latin America. Even more, Latin America can be the source of imported cases in North America and Europe, as has been happening not just with arboviral diseases, but specially with Chagas disease. When revising in bibliometric analysis such situation, also is see that there research groups outside Latin America contributing with this disease (Delgado-Osorio N, Vera-Polanía F, López-Isaza AF, Martínez-Pulgarin DF, Murillo-Abadia J, Muñoz-Urbano M, Cardona-Ospina JA, Bello R, Lagos-Grisales GJ, Villegas S, Rodríguez-Morales AJ. Bibliometric assessment of the contributions of literature on Chagas disease in Latin America and the Caribbean. Recent Pat Antiinfect Drug Discov 2014 Sep-Dec; 9(3):202-208). Then, countries such as USA, Canada, Spain, among others would be concerned about the potential impact of the spread of this arbovirus outside Latin America.

Certainly, we agree that Brazil probably is the main contributor to the issue because its budget for science is one of the highest in Latin America, and not necessarily because it suffers in a greater proportion of this problem. Nevertheless, OROV infection is a differential diagnosis in the Amazonas area of Brazil.

Finally, regard LILACS and IMBIOMED, the number of articles found in them is very limited. In the case of LILACS only 35 and at IMBIOMED none.

All these comments will be considered in the revised version that will corresponds to version 2 of this manuscript to be uploaded very soon.

Competing Interests: None.

Reviewer Report 02 March 2017

https://doi.org/10.5256/f1000research.11788.r20613

(C) 2017 Kon K. This is an open access peer review report distributed under the terms of the Creative Commons Attribution License, which permits unrestricted use, distribution, and reproduction in any medium, provided the original work is properly cited.

\section{Kateryna Kon}

Department of Microbiology, Virology and Immunology, Kharkiv National Medical University, Kharkiv, Ukraine

The study is devoted to the bibliometric analysis of research published on the emerging pathogen Oropouche virus. The title of the article is totally appropriate, the abstract provides an adequate summary of the article. There is a comprehensive explanation of study design, methods and analysis used in the study. The conclusions are well balanced and justified on the basis of the results. All sufficient information is provided for replication of results described in the study.

Competing Interests: No competing interests were disclosed.

I confirm that I have read this submission and believe that I have an appropriate level of 
expertise to confirm that it is of an acceptable scientific standard.

Author Response 02 Mar 2017

Alfonso Rodriguez-Morales, Fundación Universitaria Autónoma de las Américas, Colombia

Dear Dr. Kon

Thank you very much for your comments regard our Research Note on Bibliometrics of Oropouche virus.

Competing Interests: None.

The benefits of publishing with F1000Research:

- Your article is published within days, with no editorial bias

- You can publish traditional articles, null/negative results, case reports, data notes and more

- The peer review process is transparent and collaborative

- Your article is indexed in PubMed after passing peer review

- Dedicated customer support at every stage

For pre-submission enquiries, contact research@f1000.com 